\title{
Facile microwave-assisted hydrothermal synthesis of hexagonal sodium tungsten bronze and its high response to $\mathrm{NO}_{2}$
}

\author{
Tiago A. Martins ${ }^{\text {a }}$, Thales R. Machado ${ }^{\mathrm{a}, \mathrm{b}}$, Mateus M. Ferrer ${ }^{\mathrm{a}}$, Sonia M. Zanetti ${ }^{\mathrm{c}, *}$, \\ Elson Longo ${ }^{c}$ \\ a INCTMN-UFSCar, São Carlos, São Paulo, 13565-905 Brazil \\ ${ }^{\mathrm{b}}$ DQIO, Universitat Jaume I, Castellón, 12071 Spain \\ c INCTMN-UNESP, Araraquara, São Paulo, 14801-907 Brazil
}

\section{A R T I C L E I N F O}

\section{Article history:}

Received 21 June 2016

Received in revised form

25 August 2016

Accepted 27 August 2016

Available online 27 August 2016

Keywords:

Microwave-assisted hydrothermal method

Gas sensor

Sodium tungsten bronze

Nanoplates

\begin{abstract}
A B S T R A C T
Single-phase hexagonal sodium tungsten bronze $\left(\mathrm{h}-\mathrm{Na}_{\mathrm{x}} \mathrm{WO}_{3+\mathrm{x} / 2} \cdot \mathrm{yH} \mathrm{H}_{2} \mathrm{O}\right)$ was synthesized via a microwave-assisted hydrothermal method. A reaction time of 4 min was sufficient to obtain well-crystallized nanoplates with a thickness of 5-16 nm and length of 5-500 $\mathrm{nm}$. The structure, morphology, and composition of the obtained material were characterized by X-ray diffraction and scanning electron microscopy. $\mathrm{H}_{2} \mathrm{O}$ molecules and $\mathrm{Na}$ species were detected in the hexagonal channels of the tungsten bronze structure. The gas sensing properties were also measured, suggesting that $\mathrm{h}-\mathrm{Na}_{\mathrm{x}} \mathrm{WO}_{3+\mathrm{x} / 2} \cdot \mathrm{yH} \mathrm{H}_{2} \mathrm{O}$ can be a promising material for $\mathrm{NO}_{2}$ detection due to the high response observed.
\end{abstract}

(c) 2016 Elsevier B.V. All rights reserved.

\section{Introduction}

Tungsten bronze structures $\left(\mathrm{M}_{\mathrm{x}} \mathrm{WO}_{3}\right.$, where $\mathrm{M}$ represents species in the interstitial sites of a modified $\mathrm{WO}_{3}$ matrix) have attracted increasing attention because of their ferroelectricity, superconductivity, and potential applications including solar filters, smart windows, and humidity sensors [1-4]. However, the gas sensing properties associated to tungsten bronze structures have rarely been reported. Among other metal oxides, such as $\mathrm{SnO}_{2}, \mathrm{TiO}_{2}, \mathrm{ZnO}$, and $\mathrm{In}_{2} \mathrm{O}_{3}$, hexagonal $\mathrm{WO}_{3}$ is a well-known gas sensor with high sensitivity, selectivity, enhanced response, and recovery time [5]. Tungsten bronze structures could be potentially used for this application because of the structural similarities with $\mathrm{WO}_{3}$. Both materials are formed by octahedral $\mathrm{WO}_{6}$ arrays, which originate hexagonal channels. For $\mathrm{M}_{\mathrm{x}} \mathrm{WO}_{3}$, the hexagonal channels are filled with $\mathrm{M}$ species, including alkali metals (Cs, Li, K, and $\mathrm{Na}$ ) and some small molecules, such as water or ammonium $[2,3]$.

Moreover, these species play an important role on the final properties of the prepared materials because the presence of $\mathrm{Na}$ in $\mathrm{h}-\mathrm{Na}_{\mathrm{x}} \mathrm{WO}_{3+\mathrm{x} / 2} \cdot \mathrm{yH}_{2} \mathrm{O}$ induces the formation of trap centers, improving the photocatalytic activity. The cation also modifies the number of adsorption sites of $\mathrm{h}-\mathrm{Na}_{\mathrm{x}} \mathrm{WO}_{3+\mathrm{x} / 2} \cdot \mathrm{yH}_{2} \mathrm{O}$, which can lead to an improved response of the gas sensor.

\footnotetext{
* Corresponding author.

E-mail address: zanetti@iq.unesp.br (S.M. Zanetti).
}

Different strategies have been reported to prepare tungsten bronze structures, such as hydrothermal processes [3], solid-state reactions [6], and sol-gel methods [7]. High temperatures and/or long periods are generally necessary to synthesize single-phase tungsten bronzes $[3,6]$.

In this study, we report the synthesis of $h-\mathrm{Na}_{\mathrm{x}} \mathrm{WO}_{3+\mathrm{x} / 2} \cdot \mathrm{yH}_{2} \mathrm{O}$ using a microwave-assisted hydrothermal method, which is costeffective due to its fast kinetic process [8]. We also demonstrate that $\mathrm{h}-\mathrm{Na}_{\mathrm{x}} \mathrm{WO}_{3+\mathrm{x} / 2} \cdot \mathrm{yH}_{2} \mathrm{O}$ can act as a $\mathrm{NO}_{2}$ sensor, with the advantages of potential selectivity, facile synthesis, and high sensibility at concentrations that affect the human health [9-11].

\section{Experimental procedure}

The following procedure was used to synthesize the h- $\mathrm{Na}_{\mathrm{x}} \mathrm{WO}_{3+\mathrm{x} / 2} \cdot \mathrm{yH}_{2} \mathrm{O}$ powder. Firstly, $2 \mathrm{~g}$ of $\mathrm{Na}_{2} \mathrm{WO}_{4} \cdot 2 \mathrm{H}_{2} \mathrm{O}(99 \%$, Sigma-Aldrich) was dissolved in $45 \mathrm{~mL}$ of distilled water under stirring at room temperature for $5 \mathrm{~min}$. Then, $5 \mathrm{~mL}$ of a $3 \mathrm{M} \mathrm{HCl}$ solution was added under continuous stirring for an additional $5 \mathrm{~min}$. The yellowish product was placed in a closed Teflon reaction cell and heated using a conventional microwave furnace $(2.5 \mathrm{GHz}, 800 \mathrm{~W})$ at $150^{\circ} \mathrm{C}$ for $4 \mathrm{~min}$. The resulting precipitate was washed several times with distilled water, and dried at $80^{\circ} \mathrm{C}$ for $12 \mathrm{~h}$ under air atmosphere (MH sample). The resulting powder was heat-treated at $300{ }^{\circ} \mathrm{C}$ for $2 \mathrm{~h}$ with a heating rate of $5{ }^{\circ} \mathrm{C} \mathrm{min}{ }^{-1}$ to eliminate volatiles (MH300C sample). 
The samples were characterized by X-ray diffraction (XRD, Rigaku D/Max-2500 V/PC, Cu-Ko radiation), Raman spectroscopy (iHR550 micro-Raman spectrometer, Horiba Jobin-Yvon, Japan) coupled with a CCD detector operating with an Ar-ion laser (Melles Griot, USA), Fourier transform infrared spectroscopy (FTIR, Bruker, Equinox 55), UV-Vis absorption (Varian Cary $5 \mathrm{G}$ ), field emission scanning electron microscopy (FE-SEM, Zeiss Supra 35), and energy dispersive X-ray spectroscopy (EDX, LEO, model 440, Leica).

The sensor devices were fabricated on alumina substrates with interdigitated pre-printed $\mathrm{Ag}-\mathrm{Pd}$ electrodes on the top and a $\mathrm{Ag}-\mathrm{Pd}$ heating resistor on the bottom to control the working temperature during the measurements. The sensor elements were prepared by mixing $10 \mathrm{mg}$ of $\mathrm{h}-\mathrm{Na}_{\mathrm{x}} \mathrm{WO}_{3+\mathrm{x} / 2} \cdot \mathrm{yH}_{2} \mathrm{O}$ powder with $5 \mu \mathrm{L}$ of $\alpha-$ terpineol in a mortar to obtain a slurry that was coated on the substrate. The thick film was dried at $60^{\circ} \mathrm{C}$, followed by heating at $300{ }^{\circ} \mathrm{C}$ for $2 \mathrm{~h}$ to remove organics.

The sensing tests were carried out in a $220 \mathrm{~mL}$-glass chamber under gas flow. Synthetic air was used as both carrier and purging gas at a constant flow rate of $100 \mathrm{~cm}^{3} \mathrm{~min}^{-1}$, and $100 \mathrm{ppm}$ of $\mathrm{NO}_{2}$ in air was used as analyte gas. The desired $\mathrm{NO}_{2}$ concentrations were obtained using calibrated mass-flow controllers.

The sensor resistance was measured continuously using a Keithley 6437 picoammeter (bias voltage of $1 \mathrm{~V}$ ). Synthetic air flowed through the chamber during heating (working temperature of $200{ }^{\circ} \mathrm{C}$ ), and then the specific $\mathrm{NO}_{2}$ concentration flowed during 10 min. Finally, the $\mathrm{NO}_{2}$ flow was removed, and the chamber was purged with synthetic air during 20 min for cleaning. This procedure was repeated for each $\mathrm{NO}_{2}$ concentration (10-80 ppm). The sensor response was calculated using $S=R_{\mathrm{g}} / R_{a}$, where $R_{\mathrm{g}}$ and $R_{a}$ are the resistances in $\mathrm{NO}_{2}$ and in air flow, respectively. The response and recovery times were defined as the time required by the sensor to reach $90 \%$ of the total resistance variation in the case of adsorption and desorption, respectively.

\section{Results and discussion}

Fig. 1(a) shows the XRD patterns of the $\mathrm{MH}$ and $\mathrm{MH} 300 \mathrm{C}$ samples. All peaks were indexed to pure $\mathrm{h}-\mathrm{Na}_{\mathrm{x}} \mathrm{WO}_{3+\mathrm{x} / 2} \cdot \mathrm{yH}_{2} \mathrm{O}$ with a $P 6 / \mathrm{mmm}$ space group (Inorganic Crystal Structure Data No. 071931). Both $\mathrm{MH}$ and MH300C samples show narrow and intense diffraction peaks with a crystallite size of 22 and $15 \mathrm{~nm}$, respectively. The crystallite size decrease after the heat treatment might be related to the loss of structural water at around $300{ }^{\circ} \mathrm{C}$, which is common for hydrated tungsten oxides [12].

The FTIR and Raman bands shown in Fig. 1(b) and Fig. 1(c) are summarized in Table 1. The detected bands are in good agreement with previous studies. Specifically, the bands at 3604 and $3545 \mathrm{~cm}^{-1}$ of the FTIR spectra, and the bands at 320 and $948 \mathrm{~cm}^{-1}$
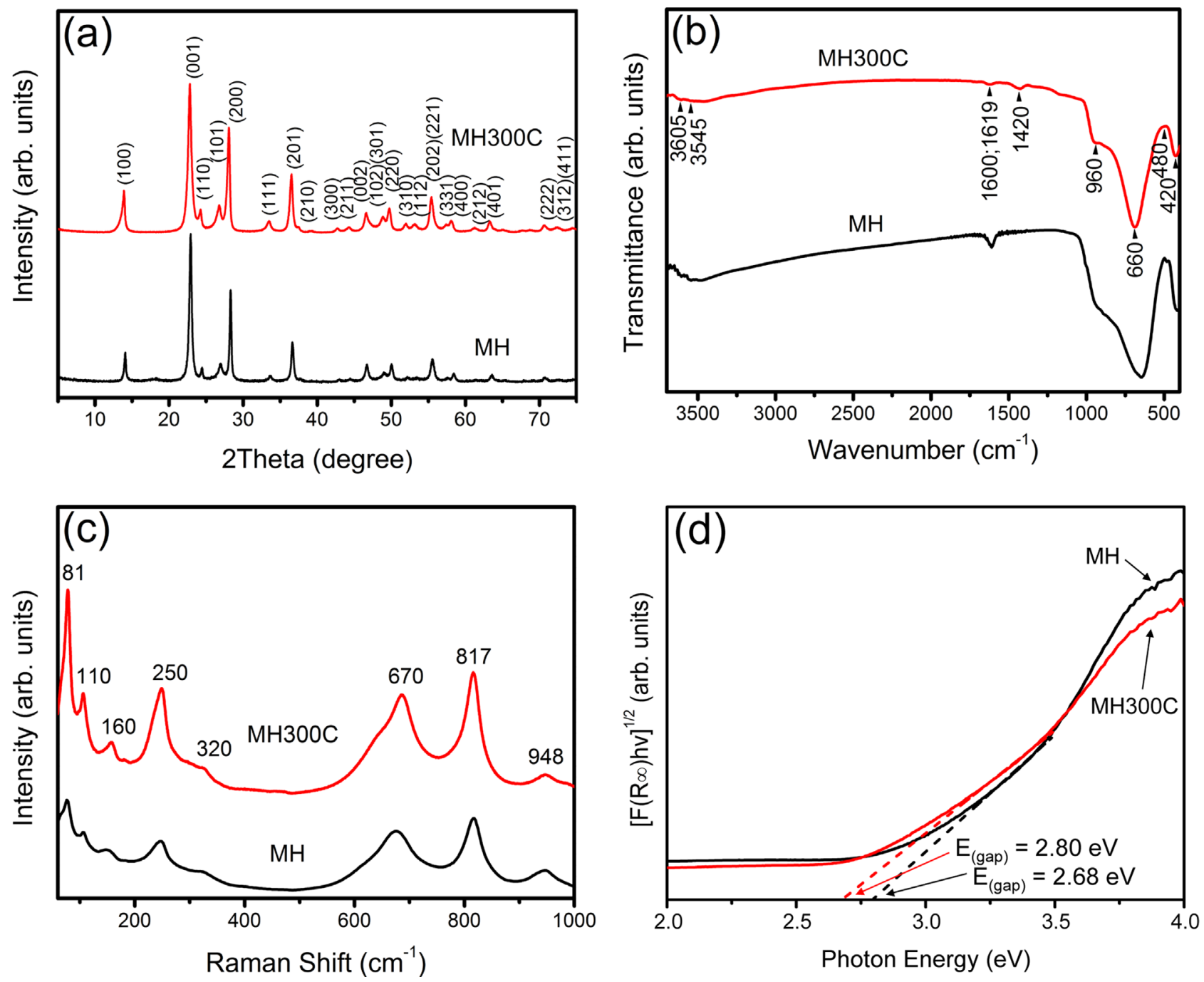

Fig. 1. (a) XRD patterns, (b) FTIR spectra, (c) Raman spectra, and (d) UV-Vis absorption spectra for the MH and MH300C samples. 
Table 1

Vibrational properties of $\mathrm{Na}_{\mathrm{x}} \mathrm{WO}_{3+\mathrm{x} / 2} \cdot \mathrm{yH}_{2} \mathrm{O}$.

\begin{tabular}{llllll}
\hline Vibrations & $\begin{array}{l}\text { FTIR band } \\
\left(\mathrm{cm}^{-1}\right)\end{array}$ & Reference & Vibrations & $\begin{array}{l}\text { Raman band } \\
\left(\mathrm{cm}^{-1}\right)\end{array}$ & Reference \\
\hline$v\left(\mathrm{~W}-\mathrm{OH}_{2}\right)$ & 420 & {$[3,19]$} & Lattice modes & 81 & {$[19]$} \\
$\delta(\mathrm{O}-\mathrm{W}-\mathrm{O})$ & 480 & {$[3]$} & & 110 & {$[19]$} \\
$v(\mathrm{O}-\mathrm{W}-\mathrm{O})$ & 660 & {$[13-19]$} & & 160 & {$[19]$} \\
$v(\mathrm{O}=\mathrm{W})$ & 960 & {$[3,19]$} & $\delta(\mathrm{O}-\mathrm{W}-\mathrm{O})$ & 250 & {$[19]$} \\
$\delta(\mathrm{OH})$ & 1410 & {$[13-19]$} & $v\left(\mathrm{~W}-\mathrm{OH}_{2}\right)$ & 320 & {$[19]$} \\
$\delta\left(\mathrm{H}_{2} \mathrm{O}\right)$ & 1600 & {$[3,13]$} & $v(\mathrm{O}-\mathrm{W}-\mathrm{O})$ & 670 & {$[19]$} \\
$\delta(\mathrm{OH})$ & 1619 & {$[3,19]$} & $v(\mathrm{O}-\mathrm{W}-\mathrm{O})$ & 817 & {$[19]$} \\
$v\left(\mathrm{H}_{2} \mathrm{O}\right)$ & 3545 & {$[3,13]$} & $v(\mathrm{~W}=\mathrm{O})$ & 948 & {$[13,19]$} \\
$v\left(\mathrm{H}_{2} \mathrm{O}\right)$ & 3605 & {$[3]$} & & & \\
\hline
\end{tabular}

$v$ for stretching vibration, and $\delta$ for bending vibration.

of the Raman spectra confirm the presence of structural water in the hexagonal channels. The presence of water and $\mathrm{Na}$ in the hexagonal channels can modify the number of adsorption sites of $\mathrm{h}-\mathrm{Na}_{\mathrm{x}} \mathrm{WO}_{3+\mathrm{x} / 2} \cdot \mathrm{yH}_{2} \mathrm{O}$, besides interacting with the electrons $(\mathrm{e}-$ ) and holes $(\mathrm{h}+)$ produced in the semiconductor, improving their electronic properties compared to $\mathrm{WO}_{3}$ [3].

The band-gap energy $\left(E_{(\text {gap })}\right)$ is related to the chemical composition of $\mathrm{h}-\mathrm{Na}_{\mathrm{x}} \mathrm{WO}_{3+\mathrm{x} / 2} \cdot \mathrm{yH}_{2} \mathrm{O}$, where $x=0.17-0.25$. If the value of $x$ is greater than 0.25 , the material exhibits a metallic character with a very small $E_{(g a p)}$ value, and the formation of tetragonal or cubic phases $[3,15]$.

Fig. 1(d) shows the UV-Vis spectra of the MH and MH300C samples; the optical band-gaps were 2.8 and $2.7 \mathrm{eV}$, respectively, using the Kubelka-Munk method [16]. These high $E_{(\text {gap })}$ values are very similar to those of $\mathrm{WO}_{3}$, which vary from 2.6 to 3.25 [17,18], confirming the formation of a hexagonal phase with a semiconductor character, which is fundamental to the sensing properties.

Fig. 2(a) and Fig. 2(b) show FE-SEM micrographs of the MH and MH300C samples, respectively. They are composed of irregular nanoplates with a thickness of 5-16 nm and length of 5-500 nm. This particle shape is commonly observed for $\mathrm{WO}_{3} \cdot \mathrm{xH}_{2} \mathrm{O}$ and $\mathrm{WO}_{3}$ materials, obtained by acidification and using $\mathrm{Na}_{2} \mathrm{WO}_{4} \cdot 2 \mathrm{H}_{2} \mathrm{O}$ as precursor [20]. The elemental analysis carried out using EDX (Fig. 2 (c)) indicated the presence of $\mathrm{W}$ (29.7 at\%), Na (2.37 at\%), and $\mathrm{O}$ (67.9 at\%) for the MH300C sample, corroborating the XRD, Raman, and FTIR results.

The $\mathrm{MH} 300 \mathrm{C}$ sample was exposed to a $\mathrm{NO}_{2}$ flow of $10,20,40$, and $80 \mathrm{ppm}$ (Fig. 3) at a working temperature of $200^{\circ} \mathrm{C}$. The sensor responses observed for these $\mathrm{NO}_{2}$ concentrations were 18 , 115,204 , and 233, respectively; these are higher or similar to those of $\mathrm{WO}_{3}$-based sensors ( 90 and 22 at $80 \mathrm{ppm}$ and $10 \mathrm{ppm}$, respectively) at $250^{\circ} \mathrm{C}[21,22]$. Moreover, a fast response time of $\sim 3 \mathrm{~min}$, and a recovery time of $\sim 12$ min were obtained for all samples. The sensor did not exhibit a good response to $\mathrm{CO}, \mathrm{CH}_{4}$, and $\mathrm{H}_{2}$, showing a potential selectivity to $\mathrm{NO}_{2}$. These results demonstrate the viability of the obtained $\mathrm{h}-\mathrm{Na}_{\mathrm{x}} \mathrm{WO}_{3+\mathrm{x} / 2} \cdot \mathrm{yH}_{2} \mathrm{O}$ structure for gas sensing applications.

We propose a sensing mechanism based on a cluster-to-cluster charge transfer, from a cluster with $\mathrm{Na}$ ions to a cluster with a neutral vacancy, as shown in the following reactions:

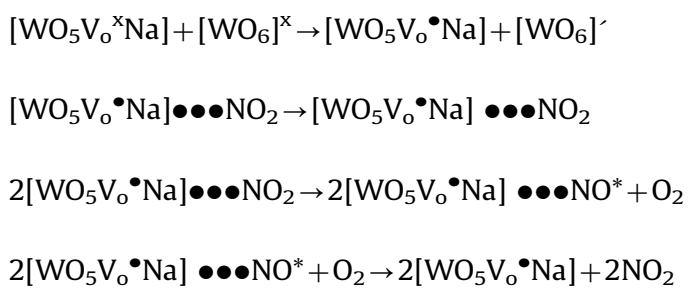

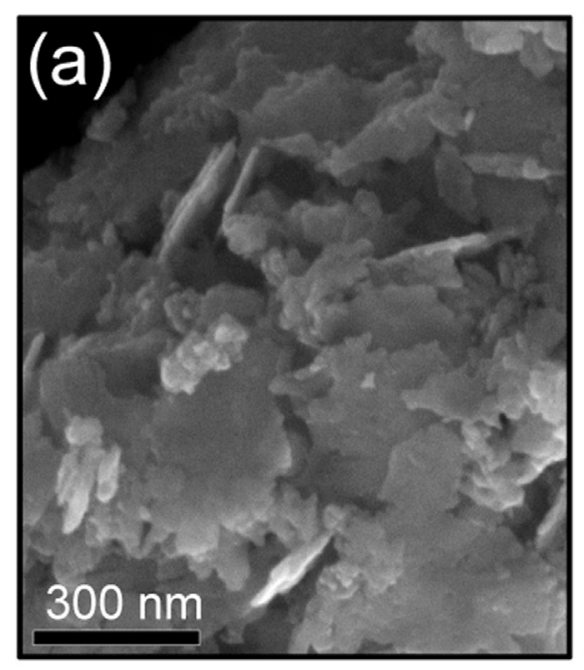
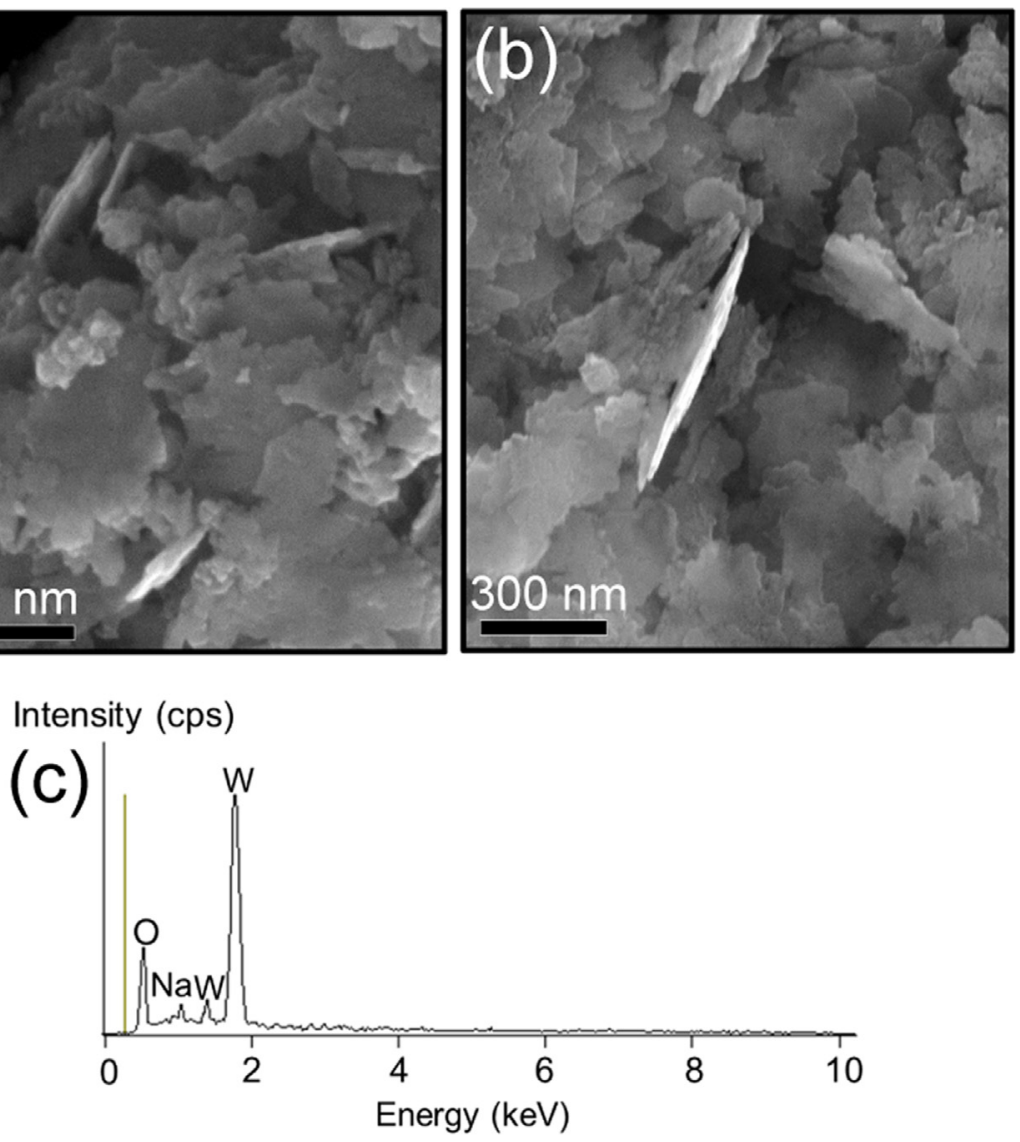

Fig. 2. FE-SEM micrographs of (a) MH, and (b) MH300C samples; (c) EDX analysis of MH300C. 


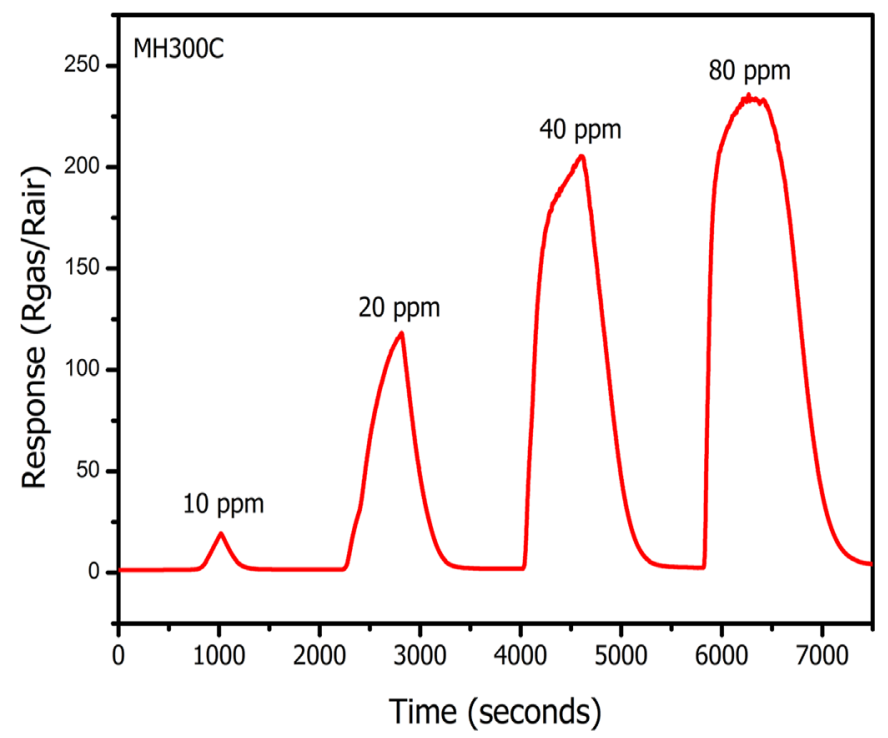

Fig. 3. Response of the $\mathrm{h}-\mathrm{Na}_{\mathrm{x}} \mathrm{WO}_{3+\mathrm{x} / 2} \cdot \mathrm{yH}_{2} \mathrm{O}$ nanoplates to $\mathrm{NO}_{2}$ at $200{ }^{\circ} \mathrm{C}$.

$\mathrm{NO}_{2}$ is adsorbed on a positive vacancy (Eq. (2)) and is subsequently dissociated (Eq. (3)) with the release of $\mathrm{O}_{2}$. After stopping the $\mathrm{NO}_{2}$ flow, the remaining $\mathrm{NO}^{*}$ molecule interacts with oxygen from air, releasing $\mathrm{NO}_{2}$ again (Eq. (4)).

\section{Conclusions}

In summary, $\mathrm{h}-\mathrm{Na}_{\mathrm{x}} \mathrm{WO}_{3+\mathrm{x} / 2} \cdot \mathrm{yH}_{2} \mathrm{O}$ nanoplates were obtained using a microwave-assisted hydrothermal methodology, which is cost-effective due to its fast kinetic process. A crystalline tungsten bronze structure was obtained at $150{ }^{\circ} \mathrm{C}$ after only 4 min of reaction. $\mathrm{H}_{2} \mathrm{O}$ molecules and $\mathrm{Na}$ species were detected in the hexagonal channels and improved their electronic properties. The nanoplates exhibited high response as a $\mathrm{NO}_{2}$ sensor, reaching values higher than 200 and a relatively fast response time ( $\sim 3 \mathrm{~min}$ ), showing potential selectivity to $\mathrm{NO}_{2}$, which involves several applications.

\section{Acknowledgments}

FAPESP (2013/07296-2 and 2013/11144-3), CNPq (INCTMN 2008/57872-1 and 573636/2008-7), and CAPES are gratefully acknowledged.

\section{References}

[1] V. Hornebecq, J.M. Réau, J. Ravez, Solid State Ion. 127 (2000) 231-240.

[2] R. Brusetti, P. Haen, J. Marcus, Phys. Rev. B 65 (2002) 144528.

[3] T. Gao, B.P. Jelle, J. Phys. Chem. C 117 (2013) 13753-13761.

[4] I. Tsuyumoto, T. Kudo, Sens. Actuators B Chem. 30 (1996) 95-99.

[5] H. Long, W. Zeng, H. Zhang, J. Mater. Sci. Mater. Electron. 26 (2015) 4698-4707.

[6] A.M. El-Sayed, S.M.A. Mousa, Pol. J. Chem. 79 (2005) 1135-1142.

[7] Y.T. Zhu, A. Manthiram, J. Solid State Chem. 110 (1994) 187-189.

[8] A.J. Paula, R. Parra, M.A. Zaghete, J.A. Varela, Mater. Lett. 62 (2008) 2581-2584.

[9] J.F. Fernández-Sánchez, T. Nezel, R. Steiger, U.E. Spichiger-Keller, Sens. Actuat ors B Chem. 113 (2006) 630-638.

[10] R. Kumar, O. Al-Dossary, G. Kumar, A. Umar, Nano-Micro Lett. 7 (2014) 1-24.

[11] P. Xu, Z. Cheng, Q. Pan, J. Xu, Q. Xiang, W. Yu, et al., Sens. Actuators B Chem. 130 (2008) 802-808.

[12] T. Zhang, J. Su, L. Guo, CrystEngComm 18 (2016) 665-669.

[13] I. Valyukh, Z. Jiao, H. Arwin, X.W. Sun, Thin Solid Films 571 (2014) 644-647.

[14] C. Wang, L. Yin, L. Zhang, D. Xiang, R. Gao, Sensors 10 (2010) 2088-2106.

[15] S. Raj, H. Matsui, S. Souma, T. Sato, T. Takahashi, A. Chakraborty, et al., Phys. Rev. B 75 (2007) 155116.

[16] L. Tolvaj, K. Mitsui, D. Varga, Wood Sci. Technol. 45 (2010) 135-146.

[17] J. Ollitrault, N. Martin, J.Y. Rauch, J.B. Sanchez, F. Berger, Mater. Lett. 155 (2015) $1-3$.

[18] Y. He, Z. Wu, L. Fu, C. Li, Y. Miao, L. Cao, et al., Chem. Mater. 15 (2003) 4039-4045.

[19] M.F. Daniel, B. Desbat, J.C. Lassegues, B. Gerand, M. Figlarz, J. Solid State Chem. 67 (1987) 235-247.

[20] B. Miao, W. Zeng, L. Lin, S. Xu, X. Ding, Nanosci. Nanotechnol. Lett. 5 (2013) 765-769.

[21] M. Penza, C. Martucci, G. Cassano, Sens. Actuators B Chem. 50 (1998) 52-59.

[22] C.S. Rout, K. Ganesh, A. Govindaraj, C.N.R. Rao, Appl. Phys. A Mater. Sci. Process. 85 (2006) 241-246. 